\title{
The Role of Nationality and Hotel Class on Guests' Satisfaction. A Fuzzy-TOPSIS Approach Applied in Saint Petersburg
}

\author{
Juan Carlos Martín ${ }^{1, *(\mathbb{D})}$, Veronika Rudchenko ${ }^{2}$ and María-Victoria Sánchez-Rebull ${ }^{3(\mathbb{C}}$ \\ 1 Department of Applied Economic Analysis, Institute of Tourism and Sustainable Economic Development, \\ University of Las Palmas de Gran Canaria, 35017 Las Palmas de Gran Canaria, Spain \\ 2 Department of Management, National Research University Higher School of Economics, \\ Saint-Petersburg 194100, Russia; erudchenko@hse.ru \\ 3 Department of Business Management, University Rovira i Virgili, 43204 Reus, Spain; \\ mariavictoria.sanchez@urv.cat \\ * Correspondence: jcarlos.martin@ulpgc.es
}

Received: 24 July 2020; Accepted: 3 September 2020; Published: 5 September 2020

\begin{abstract}
Although hotels usually have clients from different nationalities, the research analyses the multicultural effects on hotel customers' satisfaction is still scant. This paper aims to contribute to the realm of hotel management by providing interesting managerial insights into how different nationalities perceive hotel attributes differently using two hotels located in Saint Petersburg as a case study. To that end, a fuzzy hybrid method based on the technique of similarity to ideal solution (FTOPSIS) is proposed. The results are based on a sample of 447 guests and show that: (1) nationality influences the hotel guests' satisfaction; (2) customers are, in general, more elastic in three-star hotels than in four-star hotels; (3) welcome gifts in the room and in the bathroom are key attributes in the clients' satisfaction; and (4) Italian and Spanish guests are the least and the most satisfied customers, respectively. The study offers a number of important managerial insights to hotel managers and practitioners. The average figures obtained by general hotel satisfaction surveys usually hinder important peculiarities that need to be addressed when managers develop strategic satisfaction enhancement programmes. In particular, our results show that managers need to adapt the programmes to the differences observed by nationalities.
\end{abstract}

Keywords: hotel guests' satisfaction; guest nationality; multicultural analysis; fuzzy numbers; TOPSIS; key hotel attributes

\section{Introduction}

There is an increasing demand for better hotel services, mostly because the customers become more experienced and expect that the service could satisfy the individual needs. Thus, hotels are obliged to produce an adequate level of service according to new customer needs and wishes, and service quality and guests' satisfaction are considered key elements for the survival and success of the hotels. Travel behaviour and preferences could strongly vary among different cultural groups (Kim and Lee 2000). In general, Reisinger and Turner (2003) contend that satisfaction in tourism is determined by material and physical needs and its measurement can be affected by different operational buying motives, and conclude that tourists from different countries and culture can experience different levels of satisfaction because the preferences and needs are affected by the culture.

Barsky and Nash (2003) argue that only the enterprises that can adapt rapidly to the changes in customer needs and preferences can survive in the market. Gundersen et al. (1996) define customer satisfaction as a post-consumption evaluative judgement concerning a specific product. However, 
despite many attempts to explain customer satisfaction by different authors (Bowen and Clarke 2002; Kozak 2001; Neal and Gursoy 2008), a uniform definition of customer satisfaction does not exist. Nevertheless, customer satisfaction is one of the most frequently examined topics in tourism because it plays an important role in any tourist product or service (Neal and Gursoy 2008). Pizam (1999) contends that the definition of satisfaction in tourism is more problematic than in other industries as customers from different nationalities and cultures join together during the service provision. Huang et al. (1996) contend that guests' satisfaction depends on different personal traits in which culture is one of the most important ones to be considered. In this sense, cross-cultural differences do not only play a key role in tourist attractiveness but do also pose challenges in tourism industry development (Kim and McKercher 2011). In addition, Sann et al. (2020) find evidence of the existing gap that still exists in the analysis of whether the relationship between complaints made by hotel guests with respect to some attributes depend on the guests' cultural background or the hotel classification.

Nowadays, the research on understanding how cross-cultural consumer behaviour affects customers' satisfaction in the hotel industry is more crucial than ever because hotel managers are usually confronted with different cultures and preferences. In the hospitality area, cross-cultural consumer behaviour and its influence on satisfaction started only around the late 1980s (Richardson and Crompton 1988). More recently, analyses of how culture and language affect tourists' judgements in online reviews have been carried out (Alrawadieh and Law 2019; Cenni and Goethals 2017; Liu et al. 2017; Sann et al. 2020; Schuckert et al. 2015). De Carlos et al. (2018) extend the analysis taking also into consideration the country of origin, disentangling the fact that some tourists might have a second language to express the comments.

The current lodging industry confronts strong competition, and hotels are obliged to delight their guests as a managerial tool that increases profitability and survival rate (Torres and Kline 2006). The authors contend that 'customer delight' is a better approach than 'customer satisfaction' for customer relationship management (CRM), so delighting guests is now a priority for management as satisfying guests might not be enough. The authors show that customer delight is an important competitive advantage source given that policies based on implementing a culture of exceeding expectations cannot be easily copied. Thus, hotel managers need to focus on hiring the best talent and on training the employees to delight the guests adapting the behaviour to what guests might demand. In this respect, guests' nationality is a trait that cannot be undermined when hotel staff try to excel and not simply meet guests' expectations.

Thus, the aim of this paper is to shed some light in the realm of hotel management by providing interesting managerial insights into how diverse nationalities perceive hotel attributes differently in three and four-star hotels located in Saint Petersburg. For this reason, the following research questions are analysed: (RQ1) Does hotel guests' satisfaction depend on the guests' nationality? (RQ2) Is the nationality moderating effect on hotel guests' satisfaction invariant across three- and four-star hotels? (RQ3) How can hotel managers take into account the results in order to tailor the satisfaction enhancement programmes in the hotels? Thus, the following preliminary hypotheses are studied: (H1) Hotel guests' satisfaction depends on the guest's nationality; (H2) The nationality moderating effect on hotel guests' satisfaction is not uniform across different hotel class; and (H3) Hotel managers need to take into account the observed nationality moderating effect in order to envisage the guests' satisfaction enhancement programmes.

We start to contextualise the paper with a synthesis of the previous literature on cross-cultural tourist research with an emphasis on the studies that analyse the effects of guests' nationality on hotel satisfaction. Secondly, we present an overview of the questionnaire and the dataset of the case study which is grounded in two different hotels located in Saint Petersburg (Russia). Afterwards, applying a hybrid multicriteria method based on fuzzy logic and TOPSIS (FTOPSIS), we present important insights into how nationality affects the experienced hotel guests' satisfaction. Finally, at the end of the paper, we propose some satisfaction enhancement programmes in the respective hotels as an effective way to satisfy the customers more conveniently. 


\section{Literature Review}

Culture could be described as a "blueprint" of human activity that determines behaviours, preferences and satisfaction in vacation destinations visited (McCracken 1986). The national character is the core cultural element to divide customers by group to analyse their preferences, needs and satisfaction (Lenartowicz and Roth 1999). The management of cultural differences must be investigated under the context of globalisation and the growth of international enterprises (Wilson 1996). In the hotel industry, globalisation is the norm, and it is believed that a gap in customer satisfaction research exists because culturally diverse customers have different expectations and preferences (Emir 2013). Schuckert et al. (2015) review the relevant literature and find that cultural differences play a determinant role in explaining guests' perception, expectation, emphasis, and complaint toward hotel production, which are the main factors that conform guests' satisfaction.

The majority of the studies that analyse the guests' cultural differences are mainly based on primary data and statistical methods such as factor analysis (Chen and Tsai 2019; Kozak 2001; Pizam and Reichel 1996; Pizam and Sussmann 1995; Selma Ozdipciner et al. 2012), t-tests (Chen and Tsai 2019; Pizam and Sussmann 1995; Schuckert et al. 2015), analysis of variance (ANOVA) (Chen and Tsai 2019; Emir 2013; Pizam and Sussmann 1995; Selma Ozdipciner et al. 2012), and structural equation model (SEMs) (Bihamta et al. 2017; Chun et al. 2018; Reisinger and Turner 2003; Turner et al. 2002). Additionally, as we will analyse below, hotel guests' satisfaction has also been studied through hybrid multicriteria decision-making mathematical methods in which Technique for Order of Preference by Similarity to Ideal Solution (TOPSIS) have been applied jointly with fuzzy logic or machine learning (Martín et al. 2018; Nilashi et al. 2019). However, up to now, these methods have not been applied to study the effects of guests' cultural differences.

Most of the analysed studies are usually limited in the number of countries or regional areas such as Western vs. Eastern regions. Thus, clearly, there is a need to study customer satisfaction from a cross-cultural perspective as different cultural values of customers play a determinant role (Bowen and Clarke 2002; Weiermair 2000). For instance, Ahmed and Krohn (1992) indicate that American and Japanese cultures are divergent, and, consequently, the behaviour of guests is very different. A similar analysis with a different approach was done to identify the differences between British and German guests in a group of hotels in Mallorca (Spain) (Kozak 2001), and between English and non-English-speaking guests in Hong Kong hotels (Schuckert et al. 2015). Additionally, significant differences were also found between cultures (Australian, USA/Canadian, Japanese, Mandarin speakers) for different levels of satisfaction resulting from the importance emphasis given to levels of service received in Melbourne (Turner et al. 2002). Williams et al. (1998) characterised the Western cultures of North America and Europe with less interpersonal orientation, while the Eastern cultures of Asia with high social bonding. In other words, Asian cultures tend to be collectivist and to score highly on power distance and long-term orientation, whereas Western cultures mostly reveal individualism (Hofstede 1991) and are more oriented to uncertainty avoidance and individualism (Chen 2000).

In the tourism area, the intercultural perspective has also been researched analysing the effect on some key variables. For example, the tour selection made by Japanese and Korean business tourists is very different from the Australian counterparts. The first group sought suggestions and information in travel agencies, whereas Aussies preferred to use information from tourist information offices or the Internet (Hofstede 1991). The perceptions of British tour guides of Japanese, French, Italian, and American tourists are also very different. Japanese tourists were perceived to be the most distinct regarding the behavioural characteristics (Pizam and Sussmann 1995). In this sense, the differences between English and French-Canadian travellers have also been demonstrated (Sussmann and Rashcovsky 1997). Differences in the overall satisfaction of Korean and International tourists visiting South Korean Buddhist temples have also been identified (Chun et al. 2018). For international tourists, nature and relaxation are significant antecedents of satisfaction, while for Korean tourists, self-growth was an additional key significant driver. Specifically related to Russian 
Federation, Stepchenkova et al. (2015) analysed cultural differences in Russia among American and Korean tourists studying photographs of Russia posted on the net (Flickr and travel blogs). The photograph images were categorised into 10 disjoint groups as: People, Nature-Landscape, Place, Space, Transport and Infrastructure, Activities, Season, Architecture, Heritage, and State Power. Surprisingly, the authors found that in terms of image content, Americans and Koreans do not show differences in only three groups: Nature-Landscape, Activities and Season. In general, culture does not only affect needs and preferences but societal values, and values of an exciting life and pleasure are also constructs that affect the formation of travel market segments (Vinson and Munson 1976).

McCracken (1986) analyses how multicultural traits have an influence on the visitors' preferences and satisfaction. Different nationalities create different preferences among customers in tourism (Pizam and Reichel 1996). For example, Zeithaml and Bitner (1996) find that Japanese clients are the least satisfied with airline in-flight service among international travellers. The hotel industry in Spanish and Turkish resorts according to cross-cultural differences of British and German has also been addressed (Kozak 2001), and the author finds that British visitors are likely to be more satisfied than Germans for almost all the attributes included in the analysis. Medical tourism is also analysed in Yu and Ko (2012), and the authors find that Korean and Chinese segments are very different because the first group puts more emphasis on destination attributes whereas the second one shows more preference for cost levels. Schuckert et al. (2015) find that, in Hong Kong, English speaking guests rate the hotel attributes higher than non-English speaking guests who tend to be more satisfied with middle-class hotels. On the other hand, the English speaking segment prefers high-class hotels. Interestingly, the authors find that high-class hotels tend to be more homogenous in guests' satisfaction levels in comparison with low and middle-class hotels. A study conducted in a five-star hotel in Antalya (Turkey) explored the satisfaction of tourists from six different countries (Turkey, Germany, Russia, the Netherlands, Ukraine, and the United Kingdom) and concluded that satisfaction varies with respect to nationalities (Emir 2013). Turkish and German customers presented the highest levels of overall satisfaction, especially in the front office, housekeeping, and employee services, while Dutch and Ukrainian guests exhibited the lowest satisfaction levels, especially in F\&B, physical facilities, health/hygiene, customer relations, and other services.

Francesco and Roberta (2019) analyse two main issues regarding cross-country differences using online hotel reviews: (1) hotel attributes emphasis (importance); and (2) hotel attributes perception (performance). The cross-country differences are also analysed according to the hotel class and tourists' profiles. The authors find that significant cross-country differences exist and persist independently of the hotel class and tourists' profiles. The hotel class is divided into five categories from one to five stars, and the tourists' profiles are also split into five categories, namely, business, couple, friends, family, and single. The study finds that cleanliness and comfort are more important for Chinese, restaurants are more important for Italians and staff competence, and sports facilities and quietness are more important for Americans. Regarding the attributes' perception, cleanliness and quietness are more positively perceived by Americans, restaurants by Chinese and Internet and location by Italians. On the other hand, quietness, service attitude and service competence are perceived more negatively by Chinese and comfort and restaurants by Italians.

Yuksel et al. (2006) use for the first time the concept of nationality to analyse the complaining attitudes and behaviour of tourists from the UK, the Netherlands, Israel, and Turkey. The authors show that the complaining dissimilarities between them are more significant than ex-ante guests' attitudes toward complaining. Regarding the attitudes, the differences are only observed in two items. For example, the authors find that compared to Western tourists, Turkish tourists who are less individualist than the rest of the nationalities analysed may feel sad when they have to complain. The authors conclude that as Turkey can be seen as a moderate collectivist and feminine society, and caring for others has a positive value, Turkish tourists may anticipate that their complaint might create problems for some employees. On the other hand, regarding the complaining behaviour, differences are seen in six items from which voicing the satisfaction to the staff, demanding the 
intervention of a manager, and writing a letter of complaint to the headquarters are especially relevant. More recently, Sann et al. (2020) investigate online complaining behaviour with respect to six hotel attributes (service, cleanliness, room, sleep quality, location, and value) in 353 hotels using 2020 complaining reviews that represent five continents and 63 nationalities. The authors find that Asian guests are more likely to complain about service, while non-Asian guests complain more likely about cleanliness, room, sleep quality, and location. Regarding the class of the hotels, the authors also find different complaining behaviour in which high-class hotels are characterised by receiving more complaints about service and value than medium-class hotels.

\section{Questionnaire and Data}

The data was collected via a questionnaire that is considered a normal procedure in the literature of hospitality satisfaction (Armstrong et al. 1997; Gundersen et al. 1996; Kozak 2001). The survey was administered from September 2014 to June 2016 in two hotels located in Saint Petersburg that have a different class category, three- and four-star hotels, respectively. These two hotels were selected by availability reasons as hotel managers gave us permission to administer the survey on the hotel premises. The four-star hotel built in 2005 is relatively modern and it is located in the new district of the city. It has 251 rooms and 160 employees worked in the hotel during the survey administration. The three-star hotel is located in the district centre near the main historical attractions of the city. This hotel can be considered a medium-size hotel with 164 rooms.

Saint Petersburg in Russia was selected for being a paradigmatic case study within the object of our investigation. First of all, it is a convenient city to analyse the multicultural aspects of hotel guests' satisfaction as it is jointly with Moscow the most visited cities by international tourists in Russia. In fact, 7.2 million tourists (half of them international) visited the city in 2017, an increase of 4.3\% with respect to 2016 (St. Petersburg Travel Guide 2020). Secondly, it has a border location with other countries that facilitate the arrival of tourists from different countries. Thirdly, Saint Petersburg was a place for the world football championship of 2018 that also influenced the city's importance as a world tourist destination. And finally, hotel guests' satisfaction is still under-researched in Russia (Martín et al. 2018).

The questionnaire was designed after a deep literature review over customer satisfaction in tourism, putting emphasis on the hotel industry (Chand 2010; Choi and Chu 2001; Dominici and Guzzo 2010; Lee et al. 2014; Marković and Janković 2013; Matzler et al. 2006; Zhou et al. 2014). The literature review was used to set a comprehensive list of 32 attributes that proxy the hotel guests' satisfaction.

The questionnaire of four pages in length was written in Russian and translated into English in order to facilitate the administration to international tourists who do not speak Russian. A four-point semantic-type scale was used to measure the guests' satisfaction over all the attributes included in the questionnaire. The Likert scale, developed by Andrews and Withey (1976) and applied by Bitner and Hubbert (1994), is a suitable method to compile information about guests' satisfaction. During the questionnaire design and following Dolnicar (2013), it was decided to use a four-point semantic scale to measure the perception for each of the attributes included in the scale (bad = ' 1 '; fair $=$ ' 2 '; good $=$ ' 3 '; very good $=$ ' 4 ') as the inclusion of a neutral midpoint usually incorporates 'evasion' responses, and for that reason, the answer format scale was preferred to other common scales of five and seven points.

The questionnaire was initially reviewed by a professional group that consisted of the general managers of hotels and professors of universities in the field of tourism. During the focus group issues regarding the wording for the questions, the semantic scale and the labels were discussed. Finally, the questionnaire consisted of 62 questions distributed into five sections. The first part consisted of respondents' basic demographic profiles. In our study, the effects of guests' nationality are the main object of interest; so, the nationality of each respondent was asked. The following parts contained questions concerning facilities of the hotels, satisfaction, expectation and fulfilment levels over the services provided by the hotels. 
A pilot study involving 30 questionnaires was conducted on the premises of the selected hotels. After the pilot study, it was decided that the survey could be given in the hotel premises with the respondent's compromise of filling the survey and leaving it at the hotel's reception. Questionnaires were distributed to tourists personally by one of the authors of the study and by the hotels' managers. The tourists who lodged in the selected hotels older than 18 years old were the objective target of the survey. In total, 447 complete questionnaires were finally obtained and considered valid for data analysis (58\% in the four-star hotel).

Table 1 shows that, in general, among respondents, there are more males (52\%) than females (48\%). In terms of age, there are five general categories, where the most representative group is $46-55$ years $(46 \%)$, and the least representative group is $26-35$ years old $(2.5 \%)$. In total, $73 \%$ of the guests indicate business as the main purpose of the visit. With respect to the respondent's origin, the more representative nationalities are Chinese (19.5\%) and Russians (19.2\%), respectively. Chinese visited Saint Petersburg because 2017 was the year of China in Russia, and, more importantly, because a simplified visa regime between Russia and China was established in 2014. Apart from these two countries, the USA also plays a dominant position among international visitors (11.9\%) and France is the leading country in the EU $(7 \%)$.

Table 1. Guests' profile (source: compiled by authors).

\begin{tabular}{|c|c|c|c|c|c|c|}
\hline Variables & $\begin{array}{c}\text { Frequency } \\
\text { Three-Star Hotel }\end{array}$ & $\%$ & $\begin{array}{c}\text { Frequency } \\
\text { Four-Star Hotel }\end{array}$ & $\%$ & $\begin{array}{l}\text { Frequency } \\
\text { Total }\end{array}$ & $\%$ \\
\hline \multicolumn{7}{|c|}{ Gender } \\
\hline Male & 84 & 44.44 & 149 & 57.75 & 233 & 52.13 \\
\hline Female & 105 & 55.55 & 109 & 42.25 & 214 & 47.87 \\
\hline \multicolumn{7}{|c|}{ Age } \\
\hline $\begin{array}{l}\text { Under } 25 \\
\text { years }\end{array}$ & 0 & 0 & 0 & 0 & 0 & 0 \\
\hline 26-35 years & 7 & 3.70 & 4 & 1.55 & 11 & 2.46 \\
\hline $36-45$ years & 33 & 17.46 & 75 & 29.07 & 108 & 24.16 \\
\hline $46-55$ years & 63 & 33.33 & 130 & 50.39 & 193 & 43.18 \\
\hline $56-65$ years & 52 & 27.51 & 33 & 12.79 & 85 & 19.02 \\
\hline $\begin{array}{c}\text { Over } 65 \\
\text { years }\end{array}$ & 34 & 17.99 & 16 & 6.20 & 50 & 11.19 \\
\hline \multicolumn{7}{|c|}{ Nationality } \\
\hline China & 15 & 7.94 & 72 & 27.91 & 87 & 19.46 \\
\hline Russia & 42 & 22.22 & 44 & 17.05 & 86 & 19.24 \\
\hline USA & 17 & 8.99 & 36 & 13.95 & 53 & 11.86 \\
\hline France & 15 & 7.94 & 17 & 6.59 & 32 & 7.16 \\
\hline Italy & 5 & 2.65 & 13 & 5.04 & 18 & 4.03 \\
\hline UK & 6 & 3.17 & 11 & 4.26 & 17 & 3.80 \\
\hline Spain & 5 & 2.65 & 12 & 4.65 & 17 & 3.80 \\
\hline Other & 84 & 44.44 & 53 & 20.54 & 137 & 30.65 \\
\hline \multicolumn{7}{|c|}{ Purpose of the trip } \\
\hline Holidays & 92 & 48.68 & 29 & 11.24 & 121 & 27.07 \\
\hline Business & 97 & 51.32 & 229 & 88.76 & 326 & 72.93 \\
\hline
\end{tabular}

\section{Methodology}

In this paper, a hybrid method based on fuzzy logic and the technique of similarity to ideal solution FTOPSIS is applied to calculate a synthetic satisfaction indicator on the selected hotels. This method is gaining popularity to measure service quality, risk assessments, or satisfaction in different research fields like for example: (1) hotels (Ban et al. 2016; Benitez et al. 2007; Martín and Román 2017); (2) e-retailers (Yue and Yue 2018; Zhu et al. 2013); (3) railroads (Aydin 2017; Tang et al. 2017); (4) banks 
(Hosseini and Keshavarz 2017; Morsaghian et al. 2015); (5) events (Martín et al. 2017a, 2017b); (6) tourist destinations (Martín et al. 2019b); and (7) airlines (Deveci et al. 2018).

FTOPSIS techniques have been developed after the introduction of fuzzy logic (Zadeh 1965, 1973) as well-adjusted tools to handle distinct decision-making processes. Researchers find these methods very appealing when customers make choices affected by multiple attributes that feature both qualitative and quantitative aspects. Thus, the measurement of synthetic hotel guests' satisfaction indicators using the information provided by the survey is possible.

The Likert scales based on linguistic and semantic terms are more suitable to better approximate the style of human thinking. It is usually difficult to express a judgement about any attribute in the hotel as a single numeric value (crisp information). As a result, the fuzzy methods have been largely developed and applied to resolve different problems. Fuzzy methods capture the essence of the human's ambiguity judgement that deals with multidimensional attributes (Chang 1996).

In this study, we follow the approach employed by Martín and Román (2017) and Martín et al. (2019a) where triangular fuzzy numbers (TFNs) are employed to represent each of the linguistic terms answered by the respondents. The steps of the method can be synthesised as follows: (1) The raw information matrix is represented by a segment TFN information matrix; (2) The matrix obtained in the first step is clarified; (3) The ideal solutions are obtained applying TOPSIS to the obtained matrix in step 2; (4) The synthetic satisfaction indicators are obtained for each segment; and (5) the elasticity of the satisfaction is obtained for each segment with respect to all the attributes included in the scale of guests' satisfaction.

Table 2 shows how each linguistic term in the semantic scale is represented by a TFN. The definition of the TFNs, the membership function, and the fuzzy algebraic operations can be consulted in other technical papers. It can be seen that the extreme points degenerated at the beginning and end of the $0-100$ interval, and that the length of the range is 50 when the satisfaction is bad and 30 when the satisfaction is very good. Thus, the researchers assume that the uncertainty associated is higher in the inferior extreme of satisfaction than in the superior extreme. The range of the other two triangular fuzzy numbers is equal to 40 , a figure between the other two cases, and the intervals are centred symmetrically on the most likely values 50 and 70, respectively. The segmentation analysis is based on the algebra of the TFNs (Buckley 1985), and the average value for each segment is obtained as:

$$
\widetilde{A}=\left(a_{1}, a_{2}, a_{3}\right)=\left(\frac{1}{n}\right) \bullet\left(\widetilde{A_{1}} \oplus \widetilde{A_{2}} \oplus \cdots \widetilde{A_{n}}\right)=\left(\frac{\sum_{i=1}^{n} a_{1}^{(i)}, \sum_{i=1}^{n} a_{2}^{(i)}, \sum_{i=1}^{n} a_{3}^{(i)}}{n}\right)
$$

where $\widetilde{A_{i}}$ is a TFN, $\bullet$ is the external operator of a scalar and a fuzzy number, and $\oplus$ is the sum operator of fuzzy numbers. The algebra of fuzzy numbers guarantees that $\widetilde{A}$, the average value of the pair observation-attribute (hotel-attribute) over a segment of interest, nationalities, or any other sociodemographic segment, is also a TFN.

Table 2. Triangular fuzzy numbers (TFNs). Representatives of the semantic scale (source: authors' elaboration).

\begin{tabular}{cc}
\hline Linguistic Term & TFNs \\
\hline Bad & $(0,0,50)$ \\
\hline Fair & $(30,50,70)$ \\
\hline Good & $(50,70,90)$ \\
\hline Very good & $(70,100,100)$ \\
\hline
\end{tabular}

The second step serves to clarify the information obtained in the first step. Analogously to other studies, we clarify the information through the average neutral value $v_{\tilde{A}}=\left(a_{1}+2 a_{2}+a_{3}\right) / 4$ that was 
proposed by Chen (1996). This method presents a number of advantages over other more sophisticated methods as for example the simplicity and the absence of any prior requirement made by researchers about pessimism or optimism (Martín et al. 2017a).

The third step obtains the ideal solutions following the logic that the positive ideal solution is the one that maximises all the criteria associated with benefit and minimises all the criteria associated with cost, that is, for each attribute $i$ and all the observed guests' segments $j$, a vector of is obtained with the best-observed satisfaction. Similarly, the ideal negative solution is obtained with the opposite logic. Thus, the ideal solutions are computed as:

$$
\begin{aligned}
P I S & =\left\{\left(\max V_{i j} \mid j=1, \cdots, n\right), i=1,2, \ldots, m\right\} \\
N I S & =\left\{\left(\min V_{i j} \mid j=1, \cdots, n\right), i=1,2, \cdots, m\right\}
\end{aligned}
$$

PIS and NIS are then vectors defined by the number of attributes included in the satisfaction scale. The fourth step is now straightforward as the relative distance of each observation determined by each segment is now obtained with respect to the obtained ideal solutions by applying the TOPSIS method (Hwang and Yoon 1981; Zeleny 1998). Now, similarly to other ranking problems that appear in social science, the satisfaction of each of the segments can be evaluated and ranked according to the synthetic satisfaction indicator obtained by the application of TOPSIS. Thus, the segment $i$ would be more satisfied than the segment $j$ when the synthetic indicator of the $i$-observation is greater than the synthetic indicator of the $j$-observation. The ranking of all the segments according to the experienced satisfaction is now possible by comparing the synthetic satisfaction indicator obtained by TOPSIS.

Mathematically, the synthetic satisfaction index SAT for each segment $j$ is determined as follows:

$$
\begin{gathered}
S_{j}^{+}=\operatorname{dist}\left(V_{j}, P I S\right)=\sqrt{\sum_{i=1}^{m}\left(V_{i j}-P I S_{i}\right)^{2}} \quad j=1, \cdots, n \\
S_{j}^{-}=\operatorname{dist}\left(V_{j}, N I S\right)=\sqrt{\sum_{i=1}^{m}\left(V_{i j}-N I S_{i}\right)^{2}} \quad j=1, \cdots, n \\
S A T_{j}=\frac{S_{j}^{-}}{S_{j}^{+}+S_{j}^{-}} \quad j=1, \cdots, n
\end{gathered}
$$

The above equations show that the synthetic indicator of guests' hotel satisfaction depends on the distance of each observed segment with respect to the ideal solutions, and how far each observation is from the negative ideal solution. Equation (6) can be used to obtain the satisfaction that each segment experiences. This approach has been used in other hotel studies (Benitez et al. 2007; Fu et al. 2011; Martín and Román 2017; Stylos and Vassiliadis 2015).

Finally, the fifth step consists of the analysis of critical success factors that can be performed by obtaining the elasticity of SAT with respect to each attribute for particular segments of interest. The elasticity value measures how SAT varies when each of the attributes considered in the analysis changes infinitesimally. The elasticity is usually understood or defined as the percentage change variation. In mathematical notation, the elasticity can be calculated for each segment $j$, and each satisfaction attribute $i$ as:

$$
\eta_{i j}=\frac{\Delta \% S A T_{j}}{\Delta \% V_{i j}}=\frac{d S A T_{j}}{d V_{i j}} \frac{V_{i j}}{S A T_{j}}
$$

Hotel managers can use the elasticity values for each of the segments to deploy individual management programmes that enhance the guests' satisfaction for each particular segment. The knowledge of the critical attributes is crucial to plan adequate strategies in the hotel that align the triad satisfaction, loyalty, and long-term sustainability. In the current study, we show that these values 
depend on the nationality and hotel selection, so the programmes need to be individually adapted to these circumstances.

\section{Results}

For the ease of exposition, we omit here the results of the first two steps of the method in which the individual information matrix based on the semantic scale is converted to a clarified segment information matrix. Thus, we start the analysis of the results with the third step in which the ideal solutions are obtained. Table A1 shows the positive and negative ideal solutions and percentage variation for the 32 attributes of satisfaction. This table is very useful for hotel managers in order to know which attributes generate more or less satisfaction to guests, and which attributes are more or less homogeneous.

According to the obtained results for both hotels, it can be seen that there is more homogeneity in the four-star hotel. It is also remarkable that all the attributes with the exception of two attributes related with the welcome gifts show a negative value higher than 50 , that is, even in this least satisfied segment, the performance is not perceived very negatively. In some of the attributes, it can be seen that there exist some segments that evaluate the attribute at the maximum and minimum level, and this case is characterised by presenting the highest heterogeneity. Hotel managers need to evaluate whether this case is rooted in very different guests' preferences or by real differences in service performance. It is also remarkable that in the four-star hotel, a particular segment ("accommodation" — breakfast is not included) can be distinguished as the most repeated segment that evaluates negatively most of the attributes for the negative ideal solution. In this case, hotel managers need to further explore what causes can underpin this apparently hidden behaviour. It can be inferred that some guests can be very disappointed if they primarily think that they have paid a fee to have the breakfast included. For example, Lu and Zhu (2006), analysing the Chinese domestic market, find that the area of Food and Beverage is not considered important in particular hotel rating standards because the majority of the guests are not often using the service, and that this is especially relevant in the case that most of the hotels do not offer complimentary breakfast or include it in the room rate. Unfortunately, in our study, this idea could not be finally tested.

Regarding the three-star hotel, there are 10 attributes that present the highest potential level of percentage variation, so are more heterogeneous. The attributes in this set are drinks, quietness in the room, room and hotel security, furniture/decoration in restaurants and bars, view from the hotel room, hotel location (closeness to the city centre), easy reservation, and attentiveness of the front desk clerk. In the three-star hotel, we find some other attributes with an intermediate level of homogeneity in terms of satisfaction such as room furniture and hotel decoration and design. These results are similar to those obtained by Schuckert et al. (2015) in which the authors show that the satisfaction difference is also influenced by hotel class, and lower class hotels show much bigger satisfaction differences than high-class hotels. Normally, guests' satisfaction is more homogeneous in luxury hotels, whereas middle or low-class hotels usually exhibit more varied opinions.

Analysing now the observed segments in the ideal solutions, it can be seen that some relevant segments of the NIS are characterised by 'I would not visit this hotel for sure' and those who paid a very high price ('Price 501-750 euros'). The idea of the existing relationship between satisfaction and loyalty and value for money has been explored by different authors (Cheng and Abdul 2013; Jani and Han 2014). The studies find that unsatisfied guests do not recommend the hotel to friends or relatives and they do not visit the hotel again.

Moving on now to the results obtained in the fourth step-the satisfaction synthetic index, it can be seen (Figures 1 and 2) that nationality plays a moderating effect on the guests' experienced level of satisfaction. This result needs to be taken into account by hotel managers as they usually have guests from different nationalities. Figure 1 shows that Italian, British, and Chinese guests are the least satisfied in the three-star hotel. Meanwhile, guests from the UK are the least satisfied in the four-star hotel (Figure 2). Other studies have already analysed this topic. For example, Matzler et al. (2006) find 
that hotel guests' satisfaction relationship is strongly moderated by the guests' nationality, and they conclude that cross-cultural differences should be taken into account by hotel managers. Interestingly, the authors analyse the cross-cultural differences between Austrian and German guests who can be seen as closer cultures than those analysed in this study. Another interesting study analyses the main differences between domestic and foreign markets in China (Liu et al. 2017). The authors find that Chinese guests are more familiar with the local culture, language, and living environment in China, so this causes a dual effect between being less demanding for service and more demanding for hotel room characteristics and design. In our case, this issue will be discussed further with the help of the elasticities.

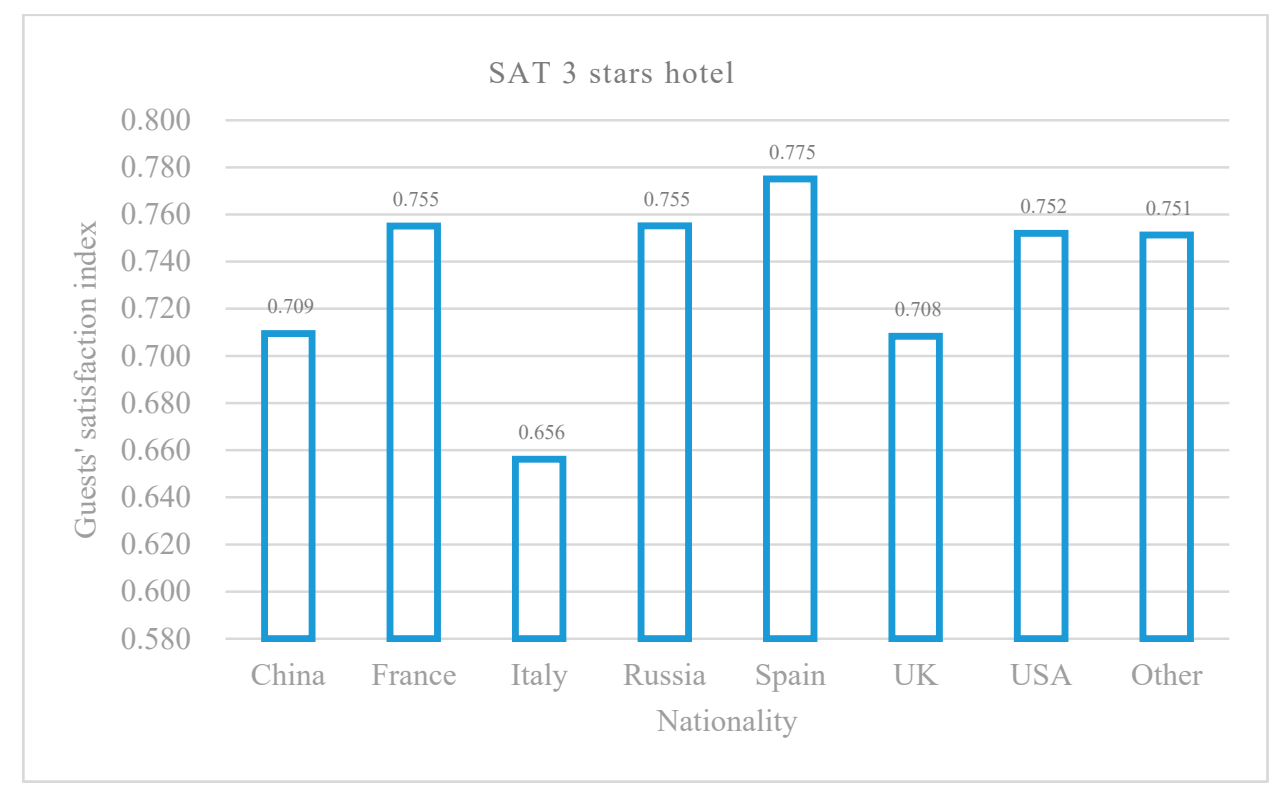

Figure 1. Guests' satisfaction index by nationality in the three-star hotel.

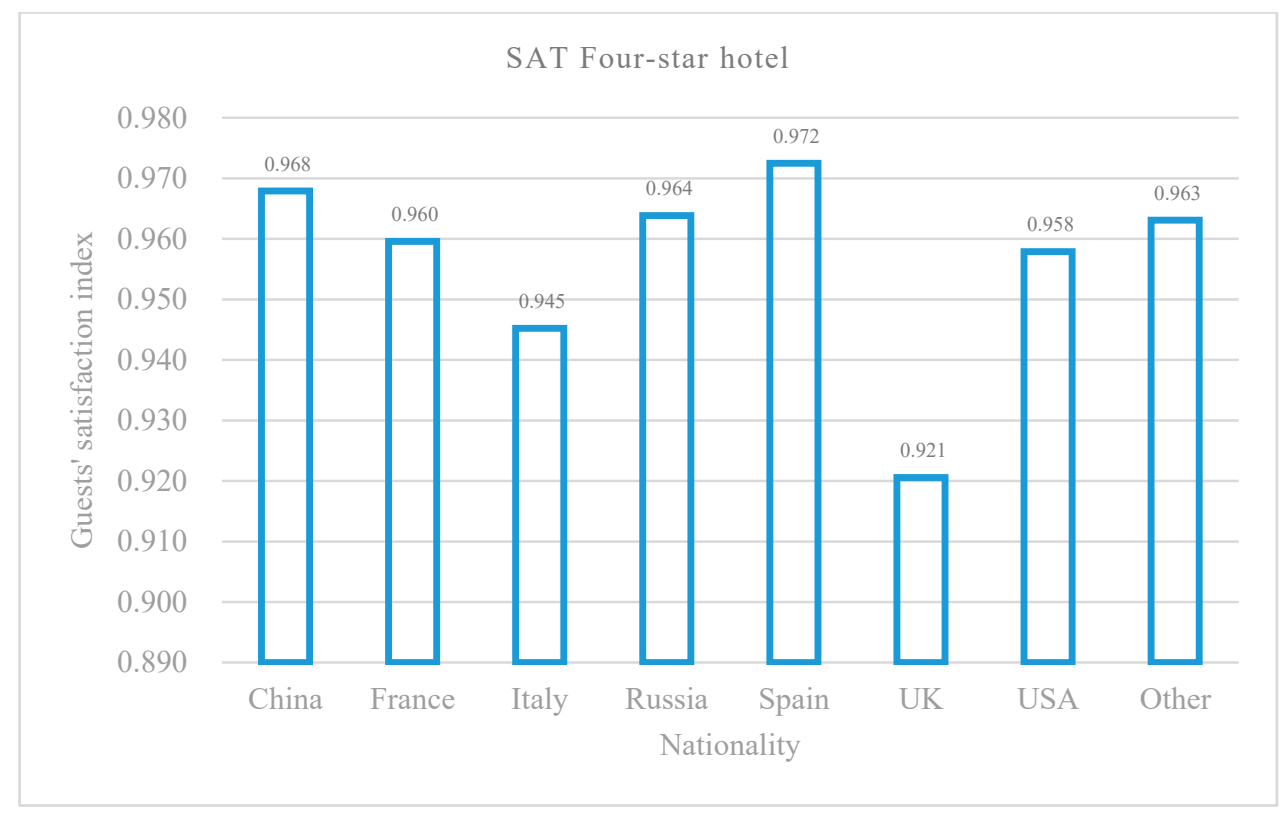

Figure 2. Guests' satisfaction index by nationality in the four-star hotel.

This section ends with the fifth step of the method-the analysis of the elasticity values (Tables A2 and A3). As explained above, the elasticity values show the percentage variation of SAT by total 
and some nationality segments with respect to a $1 \%$ variation in each of the attributes included in the analysis.

Thus, the attributes could be split according to what extent the overall guests' satisfaction is more or less elastic with respect to changes in each attribute. This information will provide very important insights to hotel managers in order to design programmes that enhance the overall guests' satisfaction.

Tables A2 and A3 inform about which attributes have more or less influence on guest satisfaction for the two hotels. As said, this information is crucial to hotel managers in order to decide the best actions they have to implement in order to improve the level of satisfaction of the guests. As we first can observe, for all attributes, guests' satisfaction is quite inelastic in the two hotels. Nevertheless, the results for the three-star hotel show that all the segments are usually less elastic with respect to the majority of the attributes than for the four-star hotel. This result is not surprising for what has already been mentioned above about the effects of hotel class on guests' satisfaction.

Table A2 shows that the most elastic values in the three-star hotel are observed in the following attributes (in parenthesis the respective nationalities are shown): Welcome gifts in the hotel room (Spanish, Russian, and other nationalities); Attentiveness of front desk (French); Welcome gifts in the bathroom (Russians and Americans). On the other hand, analysing now the most inelastic values, we obtain the following results: Attentiveness of front desk (Spanish); Restaurant a la cart (Spanish and British); Information and Signs (French and Russians); Front desk facilities (Russians); Breakfast in the restaurant (British); Easy reservation (Russians and Chinese); Front desk service (check-in) (Russians).

These results show that for the three-star hotel, it seems that SAT is more elastic with respect to some tangibles and is more inelastic with respect to services. It is especially important to the obtained result for the welcome gifts in the hotel room. This result is partly concordant with (Ariffin et al. 2005), where the authors find that "presentation of appreciation token such as welcoming drinks or gifts upon checking-in at the counter is one of the hotel hospitality ways to create surprise and excitement ... guests would be able to experience the warm welcoming even more if the hotel staff walk or guide them to their rooms upon check-in at the lobby" (p. 196). The cross-cultural differences can also be clearly explained with the results obtained for the attribute "Attentiveness of front desk", as SAT is very inelastic for Spanish guests and highly elastic for French clients. Thus, it becomes clear that the design of satisfaction enhancement programmes should be tailored having in mind that different nationalities' preferences are different.

Doing the same analysis for Table A3, it can be concluded that the most elastic values for the four-star hotel are obtained for the following attributes and nationalities: Accessibility (Spanish, Russians, Americans, and Chinese); Welcome gifts in the room, and Welcome gifts in the bathroom (Italians and Americans). On the other hand, we find that the most inelastic values are obtained for the majority of the attributes for the British segment (19 attributes out of 32). This is an interesting result that should be addressed in more depth in the future. The result of accessibility is interesting as the four-star hotel is located in a modern district of Saint Petersburg which is not conveniently located to visit the main attractions of the historical city centre. De Oliveira and Glauber (2016) finds that the most important attributes in the hotel industry are cleanliness, location, and facilities. Li and Ryan (2020) find that location in medium-class hotels acts as an excitement factor for international guests, and a performance factor for domestic guests, while for high-class hotels, location is a performance factor for all the guests. On the other hand, Sann et al. (2020) find that the rating of location is the highest of the six attributes under analysis, and conclude that guests have a high level of satisfaction with respect to the location of the hotels in comparison with the rest of the attributes. It is interesting to have in mind that these results can be considered as average results for 404 TripAdvisor listed British hotels which present at least 20 negative reviews.

According to the results, the managers of both hotels have a very different pattern of possible strategies that increase the guests' satisfaction in the hotels. In the case of the three-star hotel, managers should analyse a policy of incorporating welcome gifts in the room and in the bathroom, or even they can substitute this for a less ambitious programme like, for example, inviting the guests 
to a drink during the check-in (Ariffin et al. 2005). Nevertheless, another interesting policy that could be introduced at a very low cost is related to paying more attention to the attentiveness of the front desk especially when French guests come. For example, according to Smith (1994), hospitality is an expression of welcome by local residents to tourists who visit a particular destination. In the hotel contextualisation, the ritual of welcoming could be personally conducted according to each nationality giving some sort of appreciation between each nationality and the history of Saint Petersburg. For example, the hotel staff could recognise the intense links that exist between French history and the development of the Enlightenment period in Saint Petersburg. Meanwhile, the managers in the four-star hotel need to make further research regarding accessibility.

\section{Conclusions}

Tourism is one of the main industries in the modern economy of each country, and hospitality plays a critical role in tourism. Consequently, the increase in guest satisfaction in hospitality might determine the competitiveness of tourist destinations. Understanding tourists' levels of satisfaction is an essential point to hospitality managers for improving services, effectively promoting and creating the repetition of visits of guests. A hotel has to commit to a great deal of resources and effort to satisfy customers from different nationalities. If hotel managers are not well aware that nationalities play a determinant role in the design of satisfaction enhancement programmes, multiple problems could be present at the time of implementing them.

Our study offers very interesting practical assistance for hotel managers and other stakeholders in the hotel industry, as well as researchers in academia. One of the many interesting insights developed in the study is related to the importance of segmenting hotel guests in terms of nationality when studying the preferences and satisfaction in the hotel industry. The literature on this topic is still scarce as other types of segmentation based on gender and age have been usually more common in previous studies. Our findings indicate that the differences in the preferences of the segments under analysis are not negligible, and that the hotel class also determines important observed peculiarities.

Analysing the ideal solutions, it can be easily inferred that nationality is going to play a moderating effect on the level of guests' satisfaction because in some attributes the representative segment for some components of the PIS vector is based on some nationality. The SAT synthetic indicator shows that Italian and Chinese guests are substantially less satisfied in the three-star hotel than in the four-star hotel, so it can be concluded that the moderating effect of the nationality is not uniform in all the hotel categories. Finally, SAT is more elastic with respect to the attributes related to the welcome gifts, and the location in the four-star hotel.

The study offers a number of important managerial insights to hotel managers and practitioners. We have highlighted that the hotel is better perceived by some nationalities than others. It is true and a general fashion that hotel managers use the satisfaction surveys to analyse overall average marks, and this approach hinders important differences observed when the analysis considers guests' heterogeneity accrued by nationality. In this regard, we show that the guests' segmentation by, for example, the nationality may leverage more detailed and precise information on the peculiarities of specific hotel guests' preferences. Thus, it is clear that to increase the levels of satisfaction experienced by guests, the associated strategies need to take into account the differences observed by nationalities, and hotel managers should make an effort in developing adequate and specific satisfaction enhancement programmes for individual nationalities.

It is important to note that this study uses a hybrid fuzzy-TOPSIS model to analyse hotel guests' satisfaction on the base of 32 attributes through a survey of 447 guests in two hotels located in Saint Petersburg. However, this study also presents some limitations. Firstly, due to time and resource limitations, the researchers could only take one representative hotel of the group of three- and four-star hotels in Saint Petersburg (Russia), so we recognise that our results are neither generalisable to other hotels nor to other destinations that can greatly differ from Saint Petersburg. Secondly, the survey instrument used in this study was originally designed only in Russian and in English, and many guests 
are neither English nor Russian native speakers, so it is not easy to affirm that respondents similarly understood the wording of the questions. This is especially relevant because it might be possible that French or Spanish guests who cannot fill the questionnaire in English also hinder some differences. Thirdly, the different education, economic, cultural and social levels of responders also could influence the answers. Fourthly, other important issues related to some unexplored results of the ideal solutions such as value for money will need further attention in the future. Liu et al. (2017) find that there exists an important interaction between expectation and demands for a given value for money that is when guests perceive a high value for money the expectations are fulfilled and the guests are less harsh with the service demands. The authors conclude that the results are very likely to be generalisable to all hotel guests.

Other important extensions for future research are more related to the type of accommodation that has been used in the study. In this sense, it is difficult to anticipate whether the results can also be generalisable in luxurious five-star hotels, where a priori more homogeneous standard levels exist. New lines for future research can also be based on the analysis of the interaction of the nationalities with other segmentation variables like previous visits, length of stay, and type of accommodation. In any case, similarly to Moro et al. (2020), we affirm that, even in a globalised world, hotels need to carefully balance between a uniform production plan and adaptations to specific nationalities' preferences.

Author Contributions: Survey administration and data curation, V.R. The authors have contributed equally in the research design and development, the data analysis, and the writing of the paper. All authors have read and agreed to the published version of the manuscript.

Funding: This research received no external funding.

Acknowledgments: We acknowledge the hotel managers who gave us permission to administer the survey at the hotel premises and help us in collecting the filled questionnaires. The help support of other colleagues at our universities during the phase of the questionnaire design is also acknowledged.

Conflicts of Interest: The authors declare no conflict of interest. 


\section{Appendix A}

Table A1. Ideal Solutions (source: authors' elaboration).

\begin{tabular}{|c|c|c|c|c|c|c|c|c|c|c|}
\hline \multirow{3}{*}{ Attribute } & \multicolumn{5}{|c|}{ Three-Star Hotel } & \multicolumn{5}{|c|}{ Four-Star Hotel } \\
\hline & \multicolumn{2}{|r|}{ PIS } & \multicolumn{2}{|c|}{ NIS } & \multirow{2}{*}{$\begin{array}{c}\% \\
\text { Varia Tion }\end{array}$} & \multicolumn{2}{|c|}{ PIS } & \multicolumn{2}{|r|}{ NIS } & \multirow{2}{*}{$\begin{array}{c}\% \\
\text { Varia Tion }\end{array}$} \\
\hline & Value & Segment & Value & Segment & & Value & Segment & Value & Segment & \\
\hline Accessibility & 92.50 & 4 previous visits & 50.00 & Nights_1 & 85.00 & 92.50 & Age $\leq 35$ & 50 & Accommodation & 85.00 \\
\hline $\begin{array}{l}\text { Front desk } \\
\text { facilities }\end{array}$ & 92.50 & UK & 50.00 & Nights_1 & 85.00 & 92.50 & China & 50 & Accommodation & 85.00 \\
\hline $\begin{array}{l}\text { Information and } \\
\text { signs }\end{array}$ & 92.50 & France & 50.00 & Nights_1 & 85.00 & 92.50 & Total & 50 & Accommodation & 85.00 \\
\hline Food at breakfast & 92.50 & 5 previous visits & 50.00 & Nights_1 & 85.00 & 92.50 & $\begin{array}{c}\text { Former } \\
\text { Soviet Union }\end{array}$ & 50 & Accommodation & 85.00 \\
\hline $\begin{array}{l}\text { Food at à la carte } \\
\text { restaurant }\end{array}$ & 92.50 & 5 previous visits & 50.00 & Nights_1 & 85.00 & 92.50 & France & 50 & Nights_6 & 85.00 \\
\hline Drinks & 92.50 & 5 previous visits & 12.50 & $\begin{array}{l}\text { I would not } \\
\text { visit this } \\
\text { hotel for } \\
\text { sure }\end{array}$ & 640.00 & 92.50 & France & 50 & $\begin{array}{l}7 \text { previous visits } \\
\text { or more }\end{array}$ & 85.00 \\
\hline $\begin{array}{l}\text { Welcome gifts in } \\
\text { hotel room }\end{array}$ & 92.50 & 1 previous visit & 12.50 & $\begin{array}{l}5 \text { previous } \\
\text { visits }\end{array}$ & 640.00 & 92.50 & $\begin{array}{c}\text { Former } \\
\text { Soviet Union }\end{array}$ & 12.5 & $\begin{array}{l}\text { I would not visit } \\
\text { this hotel } \\
\text { probably }\end{array}$ & 640.00 \\
\hline $\begin{array}{l}\text { Welcome gifts in } \\
\text { bathroom }\end{array}$ & 92.50 & 1 previous visit & 12.50 & $\begin{array}{l}5 \text { previous } \\
\text { visits }\end{array}$ & 640.00 & 92.50 & Russia & 12.5 & $\begin{array}{l}\text { I would not visit } \\
\text { this hotel } \\
\text { probably }\end{array}$ & 640.00 \\
\hline
\end{tabular}


Table A1. Cont.

\begin{tabular}{|c|c|c|c|c|c|c|c|c|c|c|}
\hline \multirow{3}{*}{ Attribute } & \multicolumn{5}{|c|}{ Three-Star Hotel } & \multicolumn{5}{|c|}{ Four-Star Hotel } \\
\hline & \multicolumn{2}{|r|}{ PIS } & \multicolumn{2}{|r|}{ NIS } & \multirow{2}{*}{$\begin{array}{c}\% \\
\text { Varia Tion }\end{array}$} & \multicolumn{2}{|r|}{ PIS } & \multicolumn{2}{|r|}{ NIS } & \multirow{2}{*}{$\begin{array}{c}\% \\
\text { Varia Tion }\end{array}$} \\
\hline & Value & Segment & Value & Segment & & Value & Segment & Value & Segment & \\
\hline Room furniture & 92.50 & 1 previous visit & 31.67 & $\begin{array}{l}\text { I would not } \\
\text { recommend } \\
\text { this hotel for } \\
\text { sure }\end{array}$ & 192.11 & 92.50 & $\begin{array}{c}\text { Former } \\
\text { Soviet Union }\end{array}$ & 50 & Accommodation & 85.00 \\
\hline Quietness in room & 92.50 & 5 previous visits & 12.50 & $\begin{array}{l}\text { I would not } \\
\text { visit this } \\
\text { hotel for } \\
\text { sure }\end{array}$ & 640.00 & 92.50 & $\begin{array}{c}\text { Former } \\
\text { Soviet Union }\end{array}$ & 50 & Accommodation & 85.00 \\
\hline $\begin{array}{l}\text { Room and hotel } \\
\text { security }\end{array}$ & 92.50 & $\begin{array}{l}\text { Nights_10 or } \\
\text { more }\end{array}$ & 12.50 & $\begin{array}{l}\text { I would not } \\
\text { visit this } \\
\text { hotel for } \\
\text { sure }\end{array}$ & 640.00 & 92.50 & $\begin{array}{c}\text { Former } \\
\text { Soviet Union }\end{array}$ & 50 & Accommodation & 85.00 \\
\hline $\begin{array}{l}\text { Furniture/decoration } \\
\text { in public areas }\end{array}$ & 81.25 & Accommodation & 12.50 & $\begin{array}{l}\text { Price_501-750 } \\
\text { euros }\end{array}$ & 550.00 & 92.50 & $\begin{array}{c}\text { Former } \\
\text { Soviet Union }\end{array}$ & 50 & Accommodation & 85.00 \\
\hline $\begin{array}{l}\text { Furniture/decoration } \\
\text { in restaurants and } \\
\text { bars }\end{array}$ & 92.50 & Accommodation & 12.50 & $\begin{array}{l}\text { Price_501-750 } \\
\text { euros }\end{array}$ & 640.00 & 92.50 & $\begin{array}{c}\text { Former } \\
\text { Soviet Union }\end{array}$ & 50 & Accommodation & 85.00 \\
\hline $\begin{array}{l}\text { View from hotel } \\
\text { room }\end{array}$ & 92.50 & 7 previous visits & 12.50 & $\begin{array}{l}\text { I would not } \\
\text { visit this } \\
\text { hotel for } \\
\text { sure }\end{array}$ & 640.00 & 92.50 & France & 50 & Accommodation & 85.00 \\
\hline $\begin{array}{l}\text { Hotel location } \\
\text { (closeness to the } \\
\text { city centre) }\end{array}$ & 92.50 & USA & 12.50 & $\begin{array}{l}\text { I would not } \\
\text { visit this } \\
\text { hotel for } \\
\text { sure }\end{array}$ & 640.00 & 92.50 & Italy & 50 & Accommodation & 85.00 \\
\hline
\end{tabular}


Table A1. Cont.

\begin{tabular}{|c|c|c|c|c|c|c|c|c|c|c|}
\hline \multirow{3}{*}{ Attribute } & \multicolumn{5}{|c|}{ Three-Star Hotel } & \multicolumn{5}{|c|}{ Four-Star Hotel } \\
\hline & \multicolumn{2}{|r|}{ PIS } & \multicolumn{2}{|c|}{ NIS } & \multirow{2}{*}{$\begin{array}{c}\% \\
\text { Varia Tion }\end{array}$} & \multicolumn{2}{|c|}{ PIS } & \multicolumn{2}{|r|}{ NIS } & \multirow{2}{*}{$\begin{array}{c}\% \\
\text { Varia Tion }\end{array}$} \\
\hline & Value & Segment & Value & Segment & & Value & Segment & Value & Segment & \\
\hline $\begin{array}{l}\text { Hotel decor and } \\
\text { design }\end{array}$ & 92.50 & 7 previous visits & 37.50 & $\begin{array}{l}\text { I would not } \\
\text { visit this } \\
\text { hotel for } \\
\text { sure }\end{array}$ & 146.67 & 92.50 & $\begin{array}{c}\text { Former } \\
\text { Soviet Union }\end{array}$ & 50 & Accommodation & 85.00 \\
\hline $\begin{array}{l}\text { Front desk service } \\
\text { (check-in) }\end{array}$ & 92.50 & Nights_2 & 50.00 & Nights_1 & 85.00 & 92.50 & Italy & 50 & Accommodation & 85.00 \\
\hline $\begin{array}{l}\text { Front desk service } \\
\text { (check-in). } \\
\text { Friendliness of } \\
\text { Staff (FOS) }\end{array}$ & 92.50 & 7 previous visits & 50.00 & Nights_1 & 85.00 & 92.50 & Russia & 50 & Accommodation & 85.00 \\
\hline $\begin{array}{l}\text { Correctness of } \\
\text { reservation }\end{array}$ & 92.50 & Nights_8 & 50.00 & Nights_1 & 85.00 & 92.50 & France & 50 & Accommodation & 85.00 \\
\hline $\begin{array}{l}\text { Correctness of } \\
\text { reservation (FOS) }\end{array}$ & 92.50 & 4 previous visits & 50.00 & Nights_1 & 85.00 & 92.50 & $\begin{array}{c}\text { Former } \\
\text { Soviet Union }\end{array}$ & 50 & Accommodation & 85.00 \\
\hline Easy reservation & 92.50 & China & 12.50 & $\begin{array}{l}\text { I would not } \\
\text { visit this } \\
\text { hotel for } \\
\text { sure }\end{array}$ & 640.00 & 92.50 & Total & 50 & Age $\leq 35$ & 85.00 \\
\hline $\begin{array}{l}\text { Easy reservation } \\
\text { (FOS) }\end{array}$ & 92.50 & Italy & 50.00 & Nights_1 & 85.00 & 92.50 & $\begin{array}{c}\text { Former } \\
\text { Soviet Union }\end{array}$ & 50 & Age $\leq 35$ & 85.00 \\
\hline $\begin{array}{l}\text { Attentiveness of } \\
\text { front desk Clerk } \\
\text { (FOS) }\end{array}$ & 92.50 & Spain & 50.00 & Nights_1 & 85.00 & 92.50 & $\begin{array}{c}\text { Former } \\
\text { Soviet Union }\end{array}$ & 50 & Accommodation & 85.00 \\
\hline
\end{tabular}


Table A1. Cont.

\begin{tabular}{|c|c|c|c|c|c|c|c|c|c|c|}
\hline \multirow{3}{*}{ Attribute } & \multicolumn{5}{|c|}{ Three-Star Hotel } & \multicolumn{5}{|c|}{ Four-Star Hotel } \\
\hline & \multicolumn{2}{|r|}{ PIS } & \multicolumn{2}{|r|}{ NIS } & \multirow{2}{*}{$\begin{array}{c}\% \\
\text { Varia Tion }\end{array}$} & \multicolumn{2}{|c|}{ PIS } & \multicolumn{2}{|r|}{ NIS } & \multirow{2}{*}{$\begin{array}{c}\% \\
\text { Varia Tion }\end{array}$} \\
\hline & Value & Segment & Value & Segment & & Value & Segment & Value & Segment & \\
\hline $\begin{array}{l}\text { Attentiveness of } \\
\text { front desk clerk }\end{array}$ & 92.50 & 5 previous visits & 12.50 & $\begin{array}{l}\text { I would not } \\
\text { visit this } \\
\text { hotel for } \\
\text { sure }\end{array}$ & 640.00 & 92.50 & $\begin{array}{c}\text { Former } \\
\text { Soviet Union }\end{array}$ & 50 & Accommodation & 85.00 \\
\hline $\begin{array}{l}\text { Room cleaning at } \\
\text { the arrival }\end{array}$ & 92.50 & Nights_8 & 50.00 & Nights_1 & 85.00 & 92.50 & Total & 50 & Accommodation & 85.00 \\
\hline $\begin{array}{l}\text { Room cleaning at } \\
\text { the arrival (FOS) }\end{array}$ & 92.50 & Nights_8 & 50.00 & Nights_1 & 85.00 & 92.50 & $\begin{array}{c}\text { Former } \\
\text { Soviet Union }\end{array}$ & 50 & Accommodation & 85.00 \\
\hline $\begin{array}{l}\text { Room cleaning } \\
\text { service during the } \\
\text { stay }\end{array}$ & 92.50 & Nights_8 & 50.00 & Nights_1 & 85.00 & 92.50 & $\begin{array}{c}\text { Former } \\
\text { Soviet Union }\end{array}$ & 50 & Accommodation & 85.00 \\
\hline $\begin{array}{l}\text { Room cleaning } \\
\text { service during the } \\
\text { stay (FOS) }\end{array}$ & 92.50 & Nights_8 & 50.00 & Nights_1 & 85.00 & 92.50 & $\begin{array}{c}\text { Former } \\
\text { Soviet Union }\end{array}$ & 50 & Accommodation & 85.00 \\
\hline $\begin{array}{l}\text { Breakfast in the } \\
\text { restaurant }\end{array}$ & 92.50 & 4 previous visits & 50.00 & Nights_1 & 85.00 & 92.50 & $\begin{array}{c}\text { Former } \\
\text { Soviet Union }\end{array}$ & 50 & Accommodation & 85.00 \\
\hline $\begin{array}{l}\text { Breakfast in the } \\
\text { restaurant (FOS) }\end{array}$ & 92.50 & UK & 50.00 & Nights_1 & 85.00 & 92.50 & $\begin{array}{c}\text { Former } \\
\text { Soviet Union }\end{array}$ & 50 & Accommodation & 85.00 \\
\hline $\begin{array}{l}\text { Restaurant a la } \\
\text { cart }\end{array}$ & 92.50 & Spain & 50.00 & Nights_1 & 85.00 & 92.50 & France & 50 & $\begin{array}{l}7 \text { previous visits } \\
\text { or more }\end{array}$ & 85.00 \\
\hline $\begin{array}{l}\text { Restaurant a la } \\
\text { cart (FOS) }\end{array}$ & 92.50 & France & 50.00 & Nights_1 & 85.00 & 92.50 & Total & 50 & $\begin{array}{l}7 \text { previous visits } \\
\text { or more }\end{array}$ & 85.00 \\
\hline
\end{tabular}


Table A2. Elasticities of Guests' Satisfaction. Total and nationality. Three-Star Hotel.

\begin{tabular}{|c|c|c|c|c|c|c|c|c|c|}
\hline \multirow{2}{*}{ Attributes } & \multirow{2}{*}{ Total } & \multicolumn{8}{|c|}{ Nationality } \\
\hline & & China & France & Italy & Russia & Spain & UK & USA & Other \\
\hline Accessibility & 0.032 & 0.029 & 0.033 & 0.032 & 0.030 & 0.027 & 0.038 & 0.039 & 0.030 \\
\hline Front desk facilities & 0.031 & 0.027 & 0.027 & 0.044 & 0.027 & 0.048 & 0.019 & 0.035 & 0.031 \\
\hline Information and signs & 0.036 & 0.037 & 0.015 & 0.050 & 0.033 & 0.057 & 0.037 & 0.022 & 0.037 \\
\hline Food at breakfast & 0.042 & 0.034 & 0.027 & 0.048 & 0.040 & 0.067 & 0.038 & 0.030 & 0.044 \\
\hline Food at à la carte restaurant & 0.057 & 0.053 & 0.052 & 0.049 & 0.055 & 0.037 & 0.049 & 0.042 & 0.059 \\
\hline Drinks & 0.070 & 0.063 & 0.068 & 0.065 & 0.074 & 0.059 & 0.062 & 0.051 & 0.070 \\
\hline Welcome gifts in hotel room & 0.079 & 0.064 & 0.072 & 0.064 & 0.079 & 0.082 & 0.067 & 0.076 & 0.078 \\
\hline Welcome gifts in bathroom & 0.077 & 0.066 & 0.067 & 0.064 & 0.078 & 0.063 & 0.068 & 0.076 & 0.075 \\
\hline Room furniture & 0.046 & 0.039 & 0.049 & 0.056 & 0.047 & 0.032 & 0.048 & 0.037 & 0.045 \\
\hline Quietness in room & 0.053 & 0.051 & 0.049 & 0.063 & 0.048 & 0.037 & 0.055 & 0.040 & 0.056 \\
\hline Room and hotel security & 0.043 & 0.047 & 0.053 & 0.057 & 0.034 & 0.062 & 0.042 & 0.034 & 0.044 \\
\hline $\begin{array}{c}\text { Furniture/decoration in } \\
\text { public areas }\end{array}$ & 0.046 & 0.048 & 0.035 & 0.042 & 0.047 & 0.042 & 0.040 & 0.050 & 0.045 \\
\hline $\begin{array}{l}\text { Furniture/decoration in } \\
\text { restaurants and bars }\end{array}$ & 0.073 & 0.065 & 0.065 & 0.064 & 0.073 & 0.071 & 0.066 & 0.073 & 0.073 \\
\hline View from hotel room & 0.065 & 0.06 & 0.064 & 0.062 & 0.059 & 0.075 & 0.066 & 0.056 & 0.066 \\
\hline $\begin{array}{l}\text { Hotel location (closeness to } \\
\text { the city centre) }\end{array}$ & 0.050 & 0.044 & 0.053 & 0.062 & 0.046 & 0.056 & 0.061 & 0.028 & 0.053 \\
\hline Hotel decor and design & 0.061 & 0.059 & 0.065 & 0.055 & 0.054 & 0.041 & 0.059 & 0.055 & 0.061 \\
\hline Front desk service (check-in) & 0.030 & 0.029 & 0.042 & 0.036 & 0.021 & 0.038 & 0.026 & 0.028 & 0.031 \\
\hline $\begin{array}{l}\text { Front desk service (check-in). } \\
\text { Friendliness of Staff (FOS) }\end{array}$ & 0.038 & 0.036 & 0.042 & 0.044 & 0.040 & 0.057 & 0.043 & 0.033 & 0.034 \\
\hline Correctness of reservation & 0.034 & 0.024 & 0.023 & 0.041 & 0.027 & 0.027 & 0.037 & 0.043 & 0.037 \\
\hline $\begin{array}{l}\text { Correctness of reservation } \\
\text { (FOS) }\end{array}$ & 0.030 & 0.027 & 0.03 & 0.036 & 0.024 & 0.038 & 0.026 & 0.028 & 0.034 \\
\hline Easy reservation & 0.041 & 0.034 & 0.028 & 0.065 & 0.048 & 0.040 & 0.036 & 0.034 & 0.040 \\
\hline Easy reservation (FOS) & 0.032 & 0.022 & 0.039 & 0.026 & 0.021 & 0.030 & 0.038 & 0.042 & 0.037 \\
\hline $\begin{array}{c}\text { Attentiveness of front desk } \\
\text { clerk }\end{array}$ & 0.073 & 0.062 & 0.079 & 0.060 & 0.065 & 0.069 & 0.068 & 0.067 & 0.074 \\
\hline $\begin{array}{c}\text { Attentiveness of front desk } \\
\text { Clerk (FOS) }\end{array}$ & 0.051 & 0.051 & 0.058 & 0.043 & 0.037 & 0.014 & 0.050 & 0.060 & 0.053 \\
\hline
\end{tabular}


Table A2. Cont.

\begin{tabular}{|c|c|c|c|c|c|c|c|c|c|}
\hline \multirow{2}{*}{ Attributes } & \multirow{2}{*}{ Total } & \multicolumn{8}{|c|}{ Nationality } \\
\hline & & China & France & Italy & Russia & Spain & UK & USA & Other \\
\hline Room cleaning at the arrival & 0.035 & 0.032 & 0.041 & 0.046 & 0.033 & 0.038 & 0.026 & 0.031 & 0.034 \\
\hline $\begin{array}{l}\text { Room cleaning at the arrival } \\
\text { (FOS) }\end{array}$ & 0.039 & 0.027 & 0.033 & 0.040 & 0.037 & 0.056 & 0.038 & 0.043 & 0.041 \\
\hline $\begin{array}{l}\text { Room cleaning service } \\
\text { during the stay }\end{array}$ & 0.041 & 0.031 & 0.03 & 0.036 & 0.045 & 0.037 & 0.032 & 0.047 & 0.042 \\
\hline $\begin{array}{l}\text { Room cleaning service } \\
\text { during the stay (FOS) }\end{array}$ & 0.041 & 0.024 & 0.044 & 0.046 & 0.041 & 0.027 & 0.043 & 0.043 & 0.042 \\
\hline Breakfast in the restaurant & 0.040 & 0.041 & 0.03 & 0.041 & 0.035 & 0.027 & 0.032 & 0.030 & 0.045 \\
\hline $\begin{array}{l}\text { Breakfast in the restaurant } \\
\text { (FOS) }\end{array}$ & 0.036 & 0.027 & 0.039 & 0.032 & 0.026 & 0.027 & 0.019 & 0.028 & 0.044 \\
\hline Restaurant a la cart & 0.040 & 0.039 & 0.04 & 0.039 & 0.040 & 0.014 & 0.029 & 0.032 & 0.044 \\
\hline Restaurant a la cart (FOS) & 0.027 & 0.023 & 0.015 & 0.026 & 0.021 & 0.014 & 0.019 & 0.037 & 0.034 \\
\hline
\end{tabular}

Table A3. Elasticities of Guests' Satisfaction. Total and nationality. Four-Star Hotel.

\begin{tabular}{|c|c|c|c|c|c|c|c|c|c|}
\hline \multirow{2}{*}{ Attributes } & \multirow{2}{*}{ Total } & \multicolumn{8}{|c|}{ Nationality } \\
\hline & & China & France & Italy & Russia & Spain & UK & USA & Other \\
\hline Accessibility & 0.280 & 0.264 & 0.207 & 0.130 & 0.301 & 0.322 & 0.151 & 0.294 & 0.170 \\
\hline Front desk facilities & 0.041 & 0.021 & 0.06 & 0.055 & 0.037 & 0.024 & 0.013 & 0.052 & 0.034 \\
\hline Information and signs & 0.021 & 0.021 & 0.018 & 0.015 & 0.019 & 0.024 & 0.013 & 0.017 & 0.019 \\
\hline Food at breakfast & 0.031 & 0.021 & 0.018 & 0.015 & 0.019 & 0.024 & 0.013 & 0.017 & 0.062 \\
\hline Food at à la carte restaurant & 0.063 & 0.102 & 0.018 & 0.015 & 0.060 & 0.024 & 0.013 & 0.017 & 0.072 \\
\hline Drinks & 0.053 & 0.046 & 0.018 & 0.100 & 0.052 & 0.024 & 0.013 & 0.017 & 0.072 \\
\hline Welcome gifts in hotel room & 0.071 & 0.042 & 0.079 & 0.189 & 0.021 & 0.025 & 0.175 & 0.019 & 0.039 \\
\hline Welcome gifts in bathroom & 0.080 & 0.04 & 0.128 & 0.175 & 0.021 & 0.025 & 0.175 & 0.019 & 0.073 \\
\hline Room furniture & 0.041 & 0.047 & 0.159 & 0.015 & 0.019 & 0.024 & 0.013 & 0.017 & 0.019 \\
\hline Quietness in room & 0.059 & 0.071 & 0.159 & 0.015 & 0.019 & 0.024 & 0.013 & 0.017 & 0.073 \\
\hline Room and hotel security & 0.025 & 0.021 & 0.06 & 0.015 & 0.019 & 0.024 & 0.013 & 0.017 & 0.019 \\
\hline $\begin{array}{l}\text { Furniture/decoration in } \\
\text { public areas }\end{array}$ & 0.056 & 0.071 & 0.018 & 0.058 & 0.019 & 0.024 & 0.051 & 0.017 & 0.080 \\
\hline
\end{tabular}


Table A3. Cont.

\begin{tabular}{|c|c|c|c|c|c|c|c|c|c|}
\hline \multirow{2}{*}{ Attributes } & \multirow{2}{*}{ Total } & \multicolumn{8}{|c|}{ Nationality } \\
\hline & & China & France & Italy & Russia & Spain & UK & USA & Other \\
\hline $\begin{array}{l}\text { Furniture/decoration in } \\
\text { restaurants and bars }\end{array}$ & 0.059 & 0.071 & 0.018 & 0.058 & 0.019 & 0.024 & 0.084 & 0.017 & 0.080 \\
\hline View from hotel room & 0.067 & 0.093 & 0.018 & 0.015 & 0.037 & 0.024 & 0.071 & 0.036 & 0.072 \\
\hline $\begin{array}{l}\text { Hotel location (closeness to } \\
\text { the city centre) }\end{array}$ & 0.046 & 0.034 & 0.06 & 0.015 & 0.055 & 0.024 & 0.013 & 0.055 & 0.034 \\
\hline Hotel decor and design & 0.046 & 0.047 & 0.018 & 0.055 & 0.019 & 0.024 & 0.077 & 0.017 & 0.050 \\
\hline Front desk service (check-in) & 0.067 & 0.046 & 0.06 & 0.015 & 0.087 & 0.024 & 0.013 & 0.036 & 0.099 \\
\hline $\begin{array}{l}\text { Front desk service (check-in). } \\
\text { Friendliness of Staff (FOS) }\end{array}$ & 0.061 & 0.046 & 0.06 & 0.058 & 0.019 & 0.024 & 0.045 & 0.017 & 0.115 \\
\hline Correctness of reservation & 0.057 & 0.034 & 0.018 & 0.015 & 0.019 & 0.024 & 0.013 & 0.070 & 0.113 \\
\hline $\begin{array}{c}\text { Correctness of reservation } \\
\text { (FOS) }\end{array}$ & 0.041 & 0.021 & 0.018 & 0.015 & 0.019 & 0.024 & 0.048 & 0.017 & 0.086 \\
\hline Easy reservation & 0.021 & 0.021 & 0.018 & 0.015 & 0.019 & 0.024 & 0.013 & 0.017 & 0.019 \\
\hline Easy reservation (FOS) & 0.031 & 0.021 & 0.0721 & 0.015 & 0.019 & 0.024 & 0.062 & 0.017 & 0.019 \\
\hline $\begin{array}{l}\text { Attentiveness of front desk } \\
\text { clerk }\end{array}$ & 0.049 & 0.035 & 0.018 & 0.058 & 0.019 & 0.024 & 0.013 & 0.017 & 0.104 \\
\hline $\begin{array}{l}\text { Attentiveness of front desk } \\
\text { Clerk (FOS) }\end{array}$ & 0.053 & 0.035 & 0.018 & 0.100 & 0.019 & 0.024 & 0.013 & 0.055 & 0.076 \\
\hline Room cleaning at the arrival & 0.021 & 0.021 & 0.018 & 0.015 & 0.019 & 0.024 & 0.013 & 0.017 & 0.019 \\
\hline $\begin{array}{l}\text { Room cleaning at the arrival } \\
\text { (FOS) }\end{array}$ & 0.044 & 0.061 & 0.018 & 0.100 & 0.019 & 0.024 & 0.013 & 0.039 & 0.019 \\
\hline $\begin{array}{l}\text { Room cleaning service } \\
\text { during the stay }\end{array}$ & 0.035 & 0.046 & 0.018 & 0.055 & 0.019 & 0.024 & 0.045 & 0.017 & 0.019 \\
\hline $\begin{array}{l}\text { Room cleaning service } \\
\text { during the stay (FOS) }\end{array}$ & 0.029 & 0.035 & 0.018 & 0.015 & 0.019 & 0.024 & 0.045 & 0.017 & 0.019 \\
\hline Breakfast in the restaurant & 0.028 & 0.021 & 0.018 & 0.015 & 0.019 & 0.024 & 0.013 & 0.017 & 0.048 \\
\hline $\begin{array}{l}\text { Breakfast in the restaurant } \\
\text { (FOS) }\end{array}$ & 0.024 & 0.021 & 0.018 & 0.015 & 0.019 & 0.024 & 0.045 & 0.017 & 0.019 \\
\hline Restaurant a la cart & 0.105 & 0.146 & 0.018 & 0.015 & 0.019 & 0.024 & 0.013 & 0.061 & 0.166 \\
\hline Restaurant a la cart (FOS) & 0.021 & 0.021 & 0.018 & 0.015 & 0.019 & 0.024 & 0.013 & 0.017 & 0.019 \\
\hline
\end{tabular}




\section{References}

Ahmed, Zafar U., and Franklin B. Krohn. 1992. Understanding the unique consumer behavior of Japanese tourists. Journal of Travel \& Tourism Marketing 1: 73-86. [CrossRef]

Alrawadieh, Zaid, and Rob Law. 2019. Determinants of hotel guests' satisfaction from the perspective of online hotel reviewers. International Journal of Culture, Tourism and Hospitality Research 13: 84-97. [CrossRef]

Andrews, Frank M., and Stephen B. Withey. 1976. Social Indicators of Well-Being: American's Perceptions of Life Quality. New York: Plenum Press.

Ariffin, Muhammad A.K., Ahmad Azmi M., and Atefeh Maghzi. 2005. A preliminary study on customer expectations of hotel hospitality: Influences of personal and hotel factors. International Journal of Hospitality Management 31: 191-98. [CrossRef]

Armstrong, Robert W., Connie Mok, and Allan C.K. Chan. 1997. The importance of cross-cultural expectations in the measurement of service quality perceptions in the hotel industry. International Journal of Hospitality Management 16: 181-90. [CrossRef]

Aydin, Nezir. 2017. A fuzzy-based multi-dimensional and multi-period service quality evaluation outline for rail transit systems. Transport Policy 55: 87-98. [CrossRef]

Ban, Olimpia-Iuliana, Tara Ioan Gheorghe, Bogdan Victoria, Tuşe Delia, and Simona Gabriela Bologa. 2016. Evaluation of hotel quality attribute importance through fuzzy correlation coefficient. Technological and Economic Development of Economy 22: 471-92. [CrossRef]

Barsky, Jonathan D., and Leonard Nash. 2003. Customer satisfaction: Applying concepts to industry- wide measures. The Cornell Hotel and Restaurant Administration Quarterly 44: 173-83. [CrossRef]

Benitez, Juan Manuel, Juan Carlos Martín, and Concepcion Román. 2007. Using fuzzy number for measuring quality of service in the hotel industry. Tourism Management 28: 544-55. [CrossRef]

Bihamta, Hassan, Jayashree Sreenivasan, Rezaei Sajad, Okomus Fevzi, and Roya Rahimi. 2017. Dual pillars of hotel restaurant food quality satisfaction and brand loyalty. British Food Journal 119: 2597-609. [CrossRef]

Bitner, Mary Jo, and Amy R. Hubbert. 1994. Encounter satisfaction versus overall satisfaction versus quality: The customer's voice. In Service Quality: New Directions in Theory and Practice. Edited by Roland T. Rust and Richard L. Oliver. Thousand Oaks: Sage, pp. 72-94.

Bowen, David, and Jackie Clarke. 2002. Reflections on tourist satisfaction research: Past, present and future. Journal of Vacation Marketing 8: 297-308. [CrossRef]

Buckley, James J. 1985. Ranking alternatives. Using fuzzy numbers. Fuzzy Sets and Systems 15: 21-31. [CrossRef]

Cenni, Irene, and Patrick Goethals. 2017. Negative hotel reviews on TripAdvisor: A cross-linguistic analysis. Discourse, Context \& Media 16: 22-30. [CrossRef]

Chand, Mohinder. 2010. The impact of HRM practices on service quality, customer satisfaction and performance in the Indian hotel industry. The International Journal of Human Resource Management 21: 551-66. [CrossRef]

Chang, Da-Yong. 1996. Applications of the extent analysis method on fuzzy AHP. European Journal of Operational Research 95: 649-55. [CrossRef]

Chen, Shyi-Ming. 1996. Evaluating weapon systems using fuzzy arithmetic operations. Fuzzy Sets and Systems 77: 265-76. [CrossRef]

Chen, Joseph S. 2000. Cross-cultural differences in travel information acquisition among tourists from three Pacific-rim countries. Journal of Hospitality $\mathcal{E}$ Tourism Research 24: 239-51. [CrossRef]

Chen, Chien-Min, and Tsung-Hsein Tsai. 2019. Tourist motivations in relation to a battlefield: A case study of Kinmen. Tourism Geographies 21: 78-101. [CrossRef]

Cheng, Boon-Liat, and Abdul. 2013. Service Quality and the Mediating Effect of Corporate Image on the Relationship between Customer Satisfaction and Customer Loyalty in the Malaysian Hotel Industry. Gadjah Mada International Journal of Business 15: 99-112. [CrossRef]

Choi, Tat Y. Choi, and Raymond Chu. 2001. Determinants of hotel guests' satisfaction and repeat patronage in the Hong Kong hotel industry. International Journal of Hospitality Management 20: 277-97. [CrossRef]

Chun, Byunggil, Eugene Y. Roh, Samuel A. Spralls, and Youngjoong Kim. 2018. Predictors of Templestay Satisfaction: A Comparaison between Korean and International Participants. Leisure Sciences 40: 423-41. [CrossRef] 
De Carlos, Pablo, Alén Elisa, Pérez-González Ana, and Beatriz Figueroa. 2018. Cultural differences, language attitudes and tourist satisfaction: A study in the Barcelona hotel sector. Journal of Multilingual and Multicultural Development 40: 133-47. [CrossRef]

De Oliveira, Santos, and Eduardo Glauber. 2016. Worldwide hedonic prices of subjective characteristics of hostels. Tourism Management 52: 451-54. [CrossRef]

Deveci, Muhammet, Özcan Ender, John Robert, and Sultan Ceren Öner. 2018. Interval type-2 hesitant fuzzy set method for improving the service quality of domestic airlines in Turkey. Journal of Air Transport Management 69: 83-98. [CrossRef]

Dolnicar, Sara. 2013. Asking Good Survey Questions. Journal of Travel Research 52: 551-74. [CrossRef]

Dominici, Gandolfo, and Rosa Guzzo. 2010. Customer satisfaction in the hotel industry: A case study from Sicily. International Journal of Marketing Studies 2: 3-12. [CrossRef]

Emir, Oktay. 2013. A multi-national satisfaction analysis: An application on tourists in Antalya. Tourism 61: 347-59.

Francesco, Galati, and Galati Roberta. 2019. Cross-country analysis of perception and emphasis of hotel attributes. Tourism Management 74: 24-42. [CrossRef]

Fu, Hsin Pin, Chu Kuo-Kuang, Chao Pai, Lee Hung-Hsuan, and Yen-Chun Liao. 2011. Using fuzzy AHP and VIKOR for benchmarking analysis in the hotel industry. The Service Industries Journal 31: 2373-89. [CrossRef]

Gundersen, Marit G., Heide Morten, and Ulf H. Olson. 1996. Hotel Guest Satisfaction among Business Travelers: What are the Important Factors? The Cornell Hotel and Restaurant Administration Quarterly 37: 72-81. [CrossRef]

Hofstede, Geert. 1991. Organization and Cultures: Software of the Mind. New York: McGraw-Hill.

Hosseini, Mirza Hassan, and Elham Keshavarz. 2017. Using fuzzy AHP and fuzzy TOPSIS for strategic analysis measurement of service quality in banking industry. International Journal of Applied Management Science 9: 55-80. [CrossRef]

Huang, Jen-Hung, Huang Chun-Te, and Soushan Wu. 1996. National character and response to unsatisfactory hotel service. International Journal of Hospitality Management 15: 229-43. [CrossRef]

Hwang, Ching-Lai, and Kwangsun Yoon. 1981. Multiple Attribute Decision Making: Methods and Application. New York: Springer.

Jani, Dev, and Heesup Han. 2014. Personality, satisfaction, image, ambience, and loyalty: Testing their relationships in the hotel industry. International Journal of Hospitality Management 37: 11-20. [CrossRef]

Kim, Chulwon, and Seokho Lee. 2000. Understanding the Cultural Differences in Tourist Motivation between Anglo-American and Japanese Tourists. Journal of Travel \& Tourism Marketing 9: 153-70. [CrossRef]

Kim, Samuel Seongseop, and Bob McKercher. 2011. The collective effect of national culture and tourist culture on tourist behavior. Journal of Travel and Tourism Marketing 28: 145-64. [CrossRef]

Kozak, Metin. 2001. Comparative assessment of tourist satisfaction with destinations across two nationalities. Tourism Management 22: 391-401. [CrossRef]

Lee, Yong-Ki, Jeong Yeon-Kook, and Joowon Choi. 2014. Service quality, relationship outcomes, and membership types in the hotel industry: A survey in Korea. Asia Pacific Journal of Tourism Research 19: 300-24. [CrossRef]

Lenartowicz, Tomasz, and Kendall Roth. 1999. A framework for culture assessment. Journal of International Business Studies 30: 781-98. [CrossRef]

Li, Fangxuan, and Chris Ryan. 2020. Western guest experiences of a Pyongyang international hotel, North Korea: Satisfaction under conditions of constrained choice. Tourism Management 76: 1-11. [CrossRef]

Liu, Yong, Teichert Thorsten, Rossi Matti, Li Hongxiu, and Feng Hu. 2017. Big data for big insights: Investigating language-specific drivers of hotel satisfaction with 412,784 user-generated reviews. Tourism Management 59: 554-63. [CrossRef]

Lu, Zhen, and Feng Zhu. 2006. The post-purchase evaluation of the China's star rated hotel service quality: A content analysis of guest comments on third party hotel booking websites. The Journal of China Tourism Research 2: 93-103.

Marković, Suzana, and Sanja Raspor Janković. 2013. Exploring the relationship between service quality and customer satisfaction in Croatian hotel industry. Tourism and Hospitality Management 19: 149-64.

Martín, Juan-Carlos, and Concepcion Román. 2017. Measuring service quality in the hotel industry: The value of user generated content. Tourism 65: 390-405.

Martín, Juan Carlos, Concepcion Román, and Clara Gonzaga. 2017a. Fuzzy numbers and TOPSIS for analyzing service quality in the mice industry. Event Management 21: 13-25. [CrossRef] 
Martín, Juan Carlos, Concepcion Román, and Clara Gonzaga. 2017b. Quality of service and segmentation in the MICE industry: An approximation based on fuzzy logic. Journal of Convention E Event Tourism 18: 1-25. [CrossRef]

Martín, Juan Carlos, Maria Victoria Sánchez-Rebull, and Veronika Rudchenko. 2018. Hotel Guests' Satisfaction: A Segmentation Analysis Based on Age and Gender Using Topsis Fuzzy Methodology. Fuzzy Economic Review 23: 63-85. [CrossRef]

Martín, Juan Carlos, Luis Martín-Domingo, Gui Lohmann, and Bojana Spasojevic. 2019a. The role of travel patterns in airport duty-free shopping satisfaction: A case study from an Australian regional airport. Journal of Air Transport Management 80: 101-19. [CrossRef]

Martín, Juan Carlos, Melville Saayman, and Evangeline du Plessis. 2019b. Determining satisfaction of international tourist: A different approach. Journal of Hospitality and Tourism Management 40: 1-10. [CrossRef]

Matzler, Kurt, Birgit Renzl, and Sandra Rothenberger. 2006. Measuring the Relative Importance of Service Dimensions in the Formation of Price Satisfaction and Service Satisfaction: A Case Study in the Hotel Industry. Scandinavian Journal of Hospitality and Tourism 6: 179-96. [CrossRef]

McCracken, Grant. 1986. Culture and consumption: A theoretical account of the structure and movement of the cultural meaning of consumer goods. Journal of Consumer Research 13: 71-81. [CrossRef]

Moro, Sergio, Guilherme D Pires, Rita Paulo, and Paulo Ivo Cortez. 2020. A cross-cultural case study of consumers' communications about a new technological product. Journal of Business Research. in press. [CrossRef]

Morsaghian, Mohammad, Zadeh Iman Attar, and Sabina Nobari. 2015. Providing a way to Recognize Bank Customers' needs Effectively based on Clustering Techniques, the Fuzzy TOPSIS and Kano Model: A Case Study in Bank of Qarzollhassaneh Mehr Iran in Khuzestan. Indian Journal of Science and Technology 8: 1-10. [CrossRef]

Neal, Janet D., and Dogan Gursoy. 2008. A multifaceted analysis of tourism satisfaction. Journal of Travel Research 47: 53-62. [CrossRef]

Nilashi, Mehrbakhsh, Mardani Abbas, Liao Huchang, Ahmadi Hossein, Abdul Manaf Azizah, and Wafa Almukadi. 2019. A Hybrid Method with TOPSIS and Machine Learning Techniques for Sustainable Development of Green Hotels Considering Online Reviews. Sustainability 11: 6013. [CrossRef]

Pizam, Abraham. 1999. Cross-cultural tourist behavior. In Consumer Behavior in Travel and Tourism. Edited by Abraham Pizam and Yoel Mansfeld. New York: Haworth Press, pp. 393-412.

Pizam, Abraham, and Arie Reichel. 1996. The effect of nationality on tourist behavior: Israeli tour-guides' perceptions. Journal of Hospitality Marketing and Management 4: 3-49. [CrossRef]

Pizam, Abraham, and Silvia Sussmann. 1995. Does nationality affect tourist behavior? Annals of Tourism Research 22: 901-17. [CrossRef]

Reisinger, Yvette, and Lindsay Turner. 2003. Cross-Cultural Behavior in Tourism. Concepts and Analysis. Oxford: Butterworth-Heinemann.

Richardson, Sara L., and John L. Crompton. 1988. Latent demand for vacation travel: A cross-cultural analysis of French- and English-speaking residents of Ontario and Quebec. Leisure Sciences 10: 17-26. [CrossRef]

Sann, Raksmey, Lai Pei-Chun, and Yi Liaw. 2020. Online complaining behavior: Does cultural background and hotel class matter? Journal of Hospitality and Tourism Management 43: 80-90. [CrossRef]

Selma Ozdipciner, Nuray, Li Xiangping, and Muzaffer Uysal. 2012. Cross-cultural differences in purchase decision-making criteria. International Journal of Culture, Tourism and Hospitality Research 6: 34-43. [CrossRef]

Schuckert, Markus, Liu Xianwei, and Rob Law. 2015. A segmentation of online reviews by language groups: How English and non-English speakers rate hotels differently. International Journal of Hospitality Management 48: 143-49. [CrossRef]

Smith, Stephen L.J. 1994. The tourism product. Annals of Tourism Research 21: 582-95. [CrossRef]

St. Petersburg Travel Guide. 2020. St. Petersburg Tourism Statistics. 2017. Available online: https://guidetopetersburg.com/st-petersburg-tourism-statistics-2017/\#: \{\}:text=As\%20the\%20city \T1 textquoterights $\% 20$ tourism $\% 20$ committee, That|T1 \textquoterights $\% 20$ the $\% 20$ biggest $\% 20$ number $\% 20$ ever (accessed on 1 July 2020).

Stepchenkova, Svetlana, Kim Hany, and Anderi Kirelenko. 2015. Cultural differences in pictorial destination images: Russia through the camera lenses of American and Korean tourists. Journal of Travel Research 54: 758-73. [CrossRef] 
Stylos, Nikolaos, and Chris A. Vassiliadis. 2015. Differences in Sustainable Management Between Four-and Five-Star Hotels Regarding the Perceptions of Three-Pillar Sustainability. Journal of Hospitality Marketing $\mathcal{E}$ Management 24: 791-825. [CrossRef]

Sussmann, Silvia, and Catherine Rashcovsky. 1997. A cross-cultural analysis of English and French Canadian's vacation travel patterns. International Journal of Hospitality Management 16: 191-208. [CrossRef]

Tang, Zhaoping, Qin Jin, and Jianping Sun. 2017. Railway emergency resource dispatching optimization based on fuzzy satisfaction degree under the priority principle. Journal of Intelligent \& Fuzzy Systems 33: 2677-86. [CrossRef]

Torres, Edvin N., and Sheryl Fried Kline. 2006. From satisfaction to delight: A model for the hotel industry. International Journal of Contemporary Hospitality Management 1: 290-301. [CrossRef]

Turner, Lindsay W., Reisinger Yvette, and Lisa McQuilken. 2002. How cultural differences cause dimensions of tourism satisfaction. Journal of Travel and Tourism Marketing 11: 79-101. [CrossRef]

Vinson, Donald E., and J. Michael Munson. 1976. Personal values: An approach to market segmentation. In Marketing: 1877-1976 and Beyond. Edited by Kenneth L. Bernhardt. Chicago: AMA, pp. 313-17. [CrossRef]

Weiermair, Klaus. 2000. Tourists' perceptions towards satisfaction with service quality in the cross-cultural service encounter: Implications for hospitality and tourism management. Managing Service Quality 10: 397-409. [CrossRef]

Williams, Jerome D., Han San-Lin, and Wiliam J. Qualls. 1998. A conceptual model and study of cross-cultural business relationships. Journal of Business Research 42: 135-43. [CrossRef]

Wilson, Alan. 1996. The nature of corporate culture within a service delivery environment. Paper presented at 4th International Research Seminar in Service Management, La Londe Les Maures, France, 11 June.

Yu, Ji Yun, and Tae Gyou Ko. 2012. A cross-cultural study of perceptions of medical tourism among Chinese, Japanese and Korean tourists in Korea. Tourism Management 33: 80-88. [CrossRef]

Yue, Chuan, and Zhongliang Yue. 2018. A soft approach to evaluate the customer satisfaction in E-retailing. Advances in Intelligent Systems and Computing 646: 282-96. [CrossRef]

Yuksel, Atila, Kilinc Ugurk, and Fisun Yuksel. 2006. Cross-national analysis of hotel customers' attitudes toward complaining and their complaining behaviours. Tourism Management 27: 11-24. [CrossRef]

Zadeh, Lotfi A. 1965. Fuzzy sets. Information and Control 8: 338-53. [CrossRef]

Zadeh, Lotfi A. 1973. Outline of a new approach to the analysis of complex systems and decision processes. IEEE Transactions on Systems, Man, and Cybernetic 3: 28-44. [CrossRef]

Zeithaml, Valarie A., and Mary Jo Bitner. 1996. Services Marketing. New York: McGraw-Hill.

Zeleny, Milan. 1998. Multiple criteria decision making: Eight concepts of optimality. Human Systems Management 17: 97-107.

Zhou, Lingqiang, Ye Shun, Pearce Philip L., and Mao-Ying Wu. 2014. Refreshing hotel satisfaction studies by 871 reconfiguring customer review data. International Journal of Hospitality Management 38: 1-10. [CrossRef]

Zhu, Xiaoning, Zhang Qun, Zhang Lingping, and Jiaqin Yang. 2013. Online Promotion of the E-Commerce Websites in Retail Market in China: An Empirical Study. Journal of Electronic Commerce in Organizations 11: 23-40. [CrossRef]

(C) 2020 by the authors. Licensee MDPI, Basel, Switzerland. This article is an open access article distributed under the terms and conditions of the Creative Commons Attribution (CC BY) license (http://creativecommons.org/licenses/by/4.0/). 